Arab Univ. J. Agric. Sci., Ain Shams Univ., Cairo, 14(2), 575-589, 2006

\title{
RELATIVE ADVANTAGE OF WEED CONTROL METHODS APPLIED IN SPRINKLER AND DRIP IRRIGATED SYSTEMS IN TOMATO CULTIVATIONS IN EGYPT'S NEWLY RECLAIMED LANDS
}

[37]

\author{
Sahhar $^{1}$, E.A. and K.F. El-Bagoury ${ }^{1}$
}

\begin{abstract}
This study, based on a collaborative project with the Regional Council for Research and Agricultural Extension, was carried out at an experimental farm of a sandy soil belonging to Faculty of Agriculture, Ain Shams University, El-Bustan Region, Beheira Governorate, during two seasons (2004\&2005) on an area of 5850 $\mathrm{m}^{2}$. The experiment was designed in a split plot, arranged in a randomized complete blocks with three replications. Irrigation operations [Drip(DI)/Sprinkler(SI)] were assigned to the main plots, while weed control methods (hoe weeding/herbicide used through either conventional spraying with $0.300 \mathrm{~kg} / \mathrm{fed}$ concentration or herbigation with three herbicide concentrations of $0.150,0.225$ and $0.300 \mathrm{~kg} / \mathrm{fed}$.) were assigned to the subplots. The data were statistically analyzed by the Least Squares Method using a model involving the two factors (irrigation system and weed control method) and their interaction as affecting eradication percent, tomato yield/fed., and cost of control operation. The effect on herbicide residues in the tomatoes was also investigated.
\end{abstract}

The most important results were the following.

(1) The effect of the interaction irrigation system $\times$ weed control method was not significant ( $\mathrm{p} \geq 0.05)$ on eradication percent, tomato yield and weed control operation cost.

(2) With statistical adjustment for the control method effect, irrigation system had no significant effect $(\mathrm{p} \geq 0.05)$ on eradication percent or weed control cost. The effect on tomato yield was significant $(\mathrm{p} \leq 0.05)$; the yield under DI was greater than under SI.

(3) With statistical adjustment of irrigation system effect, the weed control method had significant effect $(\mathrm{p} \leq 0.05)$ on eradication percent, tomato yield and weed operations control cost. The following individual differences were noteworthy:

1- Ag. Eng. Dept., Fac. of Ag., Ain Shams Univ., Shoubra El-Kheima, Cairo, Egypt

(Received July 12, 2006)

(Accepted August 6, 2006) 
(a) Hoe weeding resulted in significantly $(\mathrm{p} \leq 0.05)$ higher eradication percent and tomato yield as compared with the rest of control methods used. Use of herbicide with concentration $0.150 \mathrm{~kg} / \mathrm{fed}$ resulted in lower $(\mathrm{p} \leq 0.05)$ eradication percent and tomato yield than any other weed control method.

(b) Methods of weed control did not differ ( $\mathrm{p} \geq 0.05)$ from each other in weed control operations cost.

(c) The relationship between herbicide concentration used in herbigation and eradication percent took an exponential function where the amount of superiority of SI over DI in eradication percent increases with the increase of herbicide concentration. The relationship between herbicide concentration used in herbigation and tomato yield on the other side took a quadratic equation where the superiority of DI over SI in tomato yield increases with the increase of herbicide concentration.

(4) Under either of the two irrigation systems, weed control through conventional spraying would cause more contamination with herbicide residues than herbigation with any concentration. Use of conventional spraying would result in much more (almost double) contamination when used under DI than when applied under SI. On the other hand, herbigation would result in more contamination under SI than under DI

Keywords: Hoe weeding, Conventional spraying, Herbigation, Metribuzin (Sencor) residues, Eradication percentage, Drip and sprinkler irrigation systems

\section{INTRODUCTION}

One objective of Egypt's tomato producers in newly reclaimed lands is to find a weed control procedure which can be used to improve yield per feddan through maximum weed eradication with least cost of weed control operation per ton and minimum contamination to farmers and consumers.

While mechanical cultivation is recommended from the standpoint of labor requirement, pollution of environment (Ward, 2001) and yield of marketable tomato (Alabi et al 2004), herbicides are particularly useful for inter-row weeding when it is difficult to hoe in the planted row without any damage of the plants. Use of herbicides can be significantly efficient to reduce the weed population and, thus, increase yield and net return per hectare Liaqat and Nawab, 2002 and Frost et al 2003), specially when applied through irrigation (Sujith et al 2003).

In present study, the impact of irrigation system and weed controlling procedure (hoe weeding and herbicide treatment method and concentration) was assessed when considering eradication percent, tomato yield per feddan, cost per ton of tomato and contamination as bases of comparison.

\section{MATERIAL AND METHODS}

Land and Crop: The field experiments were carried out in an experimental farm of sandy soil belonging to the Fac. of Agric., Ain Shams Univ., El-Bustan Region, Beheira Governorate in the two seasons of 2004 and 2005 under a colla- 
borative research project with Regional Council for Research and Agricultural Extension, entitled "Minimizing the Environmental Contamination with AgroChemicals Using Chemigation Techniques in New Lands". An area of about $5850 \mathrm{~m}^{2}$ was divided into two parts (Fig. 1); the first, allocated to install a permanent sprinkler irrigation system, was divided into 18 plots $(12.5 \times 18 \mathrm{~m}$ each) with 4 sprinklers per plot. The sprinklers $(1.0$ $\mathrm{m}^{3} / \mathrm{h}$ discharge at $2.2 \mathrm{~kg} / \mathrm{cm}^{2}$ working pressure) were fixed at $12 \times 12 \mathrm{~m}$ spacing. The second part, used for installing the surface drip irrigation system was divided into 18 plots (20x5 m each). A polyethylene built-in drip line (GR) from was used with the following characteristics: $20 \mathrm{~m}$ length, $0.75 \mathrm{~m}$ spacing between lines, $16 \mathrm{~mm}$ diameter and $4 \mathrm{Lph}$ flow rate/ $0.5 \mathrm{~m}$ spacing at 1.0 bar operating pressure. Tomato seedlings (Castle Rock variety) were transplanted in the second week of May of each growing season, following raising the seedlings for four weeks in the nursery. Individual plants were $0.25 \mathrm{~m}$ apart in rows. All recommended agricultural practices were applied for tomatoes production and for weed control treatments.

Weed Species: The growing weeds in the experimental field were annual (e.g. pigweed (Amaranthus caudatus L.), purslane (Portulaca oleracea v. sativa L.), spiny cocklebur (Xanthium spinosum L.), foxtail (Setaria glauca L.)) and perennial (e.g. nut sedge (Cyprus rotundus L.)).

Weed Control Material: A locally manufactured hand hoe was used to cultivate manually. A 5 L knapsack sprayer was used as conventional sprayer of herbicide with single nozzle and hand pump (discharge rate of $20 \mathrm{~L} / \mathrm{h}$ with spraying pres- sure of $\left.3 \mathrm{~kg} / \mathrm{cm}^{2}\right)$. Metribuzin [4-amino6(1,1-dimethyl)-3-(methylthio)-1,2,4triazin-5(4H)] $\left(\right.$ Sencor $^{\circledR}$, Lexone ${ }^{\circledR}$ ) was used as herbicide for conventional spraying $(0.300 \mathrm{~kg} / \mathrm{fed})$ and herbigation $(0.150$, 0.225 and $0.300 \mathrm{~kg} / \mathrm{fed})$. It is a white, crystalline solid with a slightly sharp, sulfurous odor, of high solubility in water and low tendency to be adsorbed by most soil. While the half-life of metribuzin in pond water is approximately 7 days, its hydrolysis half-life is 9 to 28 weeks.

Experimental Design: The experiment was designed in a split plot, arranged in a randomized complete block with three replications. Irrigation operations were assigned to main plots while weed control methods were assigned to the subplots (Fig. 2).

\section{Weed Control Methods}

(a) Hoe weeding: In week 3 following transplanting, soil was cultivated using a locally manufactured hoe.

(b) Conventional spraying: Metribuzin at an application intensity of 0.300 $\mathrm{kg} /$ fed. was sprayed once only on day 21 from transplanting; the herbicide was applied on weeds directly using a knapsack sprayer.

(c) Herbigation: Metribuzin at application intensities of $\mathrm{C}_{1}=0.150, \mathrm{C}_{2}=$ 0.225 and $\mathrm{C}_{3}=0.300 \mathrm{~kg} / \mathrm{fed}$. (represents 50, 75 and $100 \%$ of MOA recommendations) was applied through irrigation water using surface drip and sprinkler irrigation systems on day 21 following transplanting. Details on application rate and time are given in Table (1). 
Table 1. The herbicide concentrations, application rates and application times for irrigation systems.

\begin{tabular}{|cccc|}
\hline Irrigation system & $\begin{array}{c}\text { Herbicide concentration, } \\
\mathrm{kg} / \text { fed. }\end{array}$ & $\begin{array}{c}\text { Application rate, } \\
\text { l/min. }\end{array}$ & $\begin{array}{c}\text { Application time, } \\
\text { min. }\end{array}$ \\
\hline \multirow{2}{*}{ Drip } & 0.150 & 3 & 9 \\
& 0.225 & 2.2 & 13 \\
& 0.300 & 1.5 & 18 \\
\hline Sprinkler & 0.150 & 4 & 5 \\
& 0.225 & 3 & 7 \\
\hline
\end{tabular}

\section{Bases of Comparison}

(a) Eradication percentage $\left(\boldsymbol{P}_{\boldsymbol{e}}\right)$. The eradication percentage of weed control was calculated as follows

$$
P_{e}=\frac{W_{o}-W_{R}}{W_{o}} \times 100,
$$

where: $\boldsymbol{W}_{\boldsymbol{O}}$ : weight of weeds manually collected from unweeded plot, $\mathrm{kg} / \mathrm{m}^{2}$ and $W_{R}$ : weight of weeds collected after treatment, $\mathrm{kg} / \mathrm{m}^{2}$.

Weeds were collected on week 5 following transplanting from randomly selected areas ( $1 \mathrm{~m}$ by $1 \mathrm{~m}$ quadrate) within each plot, and biomass was determined .

(b) Tomato yield. The marketable fruits were manually picked at 7-day intervals (beginning from week 8 after transplanting) and weighed. The sample area was of $10 \mathrm{~m}$ along the central planting row in the middle of the plot. The two outer ridges were excluded to eliminate the border effect.

(c) Cost of weed control operation. The itemized costs (LE/fed.) were estimated as follows

(i)- Cost of hoe weeding $\left(\boldsymbol{C}_{\boldsymbol{h o}}\right)$ was calculated using the following equation:

$$
C_{h o}=N \times L \times T,
$$

where: $N=$ Number of operators required to hoeing one feddan; $\boldsymbol{L}=$ Operator hourly salary, LE/h; and $\boldsymbol{T}=$ Hoeing time, $\mathrm{h} / \mathrm{fed}$.

(ii)- Cost of chemical weed control methods $\left(\boldsymbol{C}_{\boldsymbol{W}}\right)$ using knapsack sprayer or herbigation was calculated as follows

$$
C_{W}=\left(C_{h} \times T\right)+\left(Q_{h} \times P_{h}\right),
$$


where: $\boldsymbol{C}_{\boldsymbol{h}}=$ Hourly operating costs of knapsack sprayer or venturi in herbigation system, LE/h; $\boldsymbol{T}=$ Herbicide application time, h/fed.; $\boldsymbol{Q}_{\boldsymbol{h}}=$ Herbicide quantity, $\mathrm{kg} / \mathrm{fed}$; and $\boldsymbol{P}_{\boldsymbol{h}}=$ Herbicide price, $\mathrm{LE} / \mathrm{kg}$.

To determine hourly operating costs $\left(\boldsymbol{C}_{\boldsymbol{h}}\right)$ of herbicide applicator (sprayer or venturi) the following equation (Awady et al 2003) was used with units have to be homogeneous on both sides of the equation:

where

$$
C_{h}=\frac{P}{h}\left(\frac{1}{a}+\frac{I}{2}+t+r\right)+\frac{m}{144},
$$

$\boldsymbol{P}=$ Price, LE.

for sprayer: 100; for venturi: 950 ;

$\boldsymbol{h}=$ Yearly working hours, $\mathrm{h} / \mathrm{yr}$

for sprayer: 100; for venturi: 300 ;

$\boldsymbol{a}=$ Life expectancy, years

for sprayer: 2; for venturi: 10 ;

$\boldsymbol{I}=$ Interest rate /year

for sprayer: $10 \%$; for venturi: $10 \%$;

$\boldsymbol{t}=$ Taxes and overheads ratio, $/ \mathrm{yr}$

for sprayer: $2 \%$; for venturi: $2 \%$;

$\boldsymbol{r}=$ Repairs and maintenance cost for sprayer: $120 \%$ of the depreciation; for venture: ---;

$\boldsymbol{m}=$ Operator monthly salary, LE./month for sprayer: 300; for venturi: ---;

$\mathbf{1 4 4 =}$ The operator monthly average working hours

for either sprayer or venturi.

(d) Evaluation of tomato fruits contamination percent:Residues of the metribuzin were separated from tomato fruits, identified and determined quantitatively using gas chromatographic technique according at A.O.A.C. (1990) at the Toxicity Unit of, Fac. of Agric., Ain Shams Univ.
Statistical Analysis: The data were analyzed using Least Squares Method (SAS, 1988) according the following model:

$$
\mathbf{Y}_{\mathrm{ijk}}=\mathbf{u}+\mathbf{I}_{\mathrm{i}}+\mathbf{M}_{\mathbf{j}}+\left(\mathbf{I}^{*} \mathbf{M}\right)_{\mathrm{ij}}+\mathbf{e}_{\mathrm{ijk}},
$$

where

Yijk is the observation (eradication percent, tomato yield or cost of weeding) of $\mathrm{k}^{\text {th }}$ record in the $\mathrm{i}^{\text {th }}$ irrigation system and $\mathrm{j}^{\text {th }}$ weeding method;

is the overall mean of $\mathrm{Y}$;

$\mathrm{u} \quad$ is the

$I_{i} \quad$ is the effect of irrigation systems ( $\mathrm{i}=1$ and 2);

$\mathrm{M}_{\mathrm{j}} \quad$ is the effect of weeding method $(j=1,2,34$ and 5);

$\left(I^{*} \mathrm{M}\right)_{\mathrm{ij}} \quad$ is the effect of the interaction between $i^{\text {th }}$ irrigation system and $\mathrm{j}^{\text {th }}$ weed control method; and

eijk is the effect of random error.

Whenever the effect of interaction is statistically non-significant $(\mathrm{p} \geq 0.05)$, the significance of differences between individual means were tested using Duncan's Multiple Range test (Duncan, 1955).

\section{RESULTS AND DISCUSSION}

The results of analysis of variance of eradication percent, tomato yield and cost of weed control operations are given in Table (2). The interaction between irrigation system and weed control method was found not statistically significant $(\mathrm{p} \geq 0.05)$ in the three cases.

Eradication percent $\left(\mathbf{P}_{\mathbf{e}}\right)$ : With statistical adjustment of the weed control method effect, irrigation system had no statistically significant effect on $\mathrm{P}_{e}$ 
( $\mathrm{p} \geq 0.0001$ ), the difference in $\mathrm{P}_{\mathrm{e}}$ between the sprinkler system $(51.02 \%)$ and the drip system $(48.83 \%)$ being not statistically significant ( $\mathrm{p} \geq 0.05)$.

With statistical adjustment of the irrigation system effect, the weed control method had significant effect on $\mathrm{P}_{\mathrm{e}}$ $(p \leq 0.0001)$. Hoe weeding showed higher $\mathrm{P}_{\mathrm{e}}$ than any other weeding method $(\mathrm{p} \leq 0.05)$. The only exception was conventional spraying which gave comparable results $(p \geq 0.05)$ as hoe weeding. The superiority of hoe weeding and conventional spraying over an other weed control methods is due to two facts. With hoe weeding (contrary to the other weed control) most control weeds are removed during hoeing process before being ejected out of the field. With the conventional spraying the absorption of herbicide through the weed before surface is faster than any other weed control method. Herbigation with herbicide concentration of $0.150 \mathrm{~kg} / \mathrm{fed}$. presented significantly lower $\mathrm{P}_{\mathrm{e}}$ than any other weed control method $(p \leq 0.05)$. It seems that the $0.150 \mathrm{~kg} /$ fed concentration of the herbicide is so low that its use un recommendable through herbigation. Conventional spraying did not differ significantly $(\mathrm{p} \geq 0.05)$ in $\mathrm{P}_{\mathrm{e}}$ from herbigation with $0.300 \mathrm{~kg} / \mathrm{fed}$, which in turn was significantly similar $(p \geq 0.05)$ to herbigation with herbicide concentration of 0.225 $\mathrm{kg} / \mathrm{fed}$. These results would lead to conclude that herbicide concentration in herbigation should be increased to obtain Pe results similar to those achieved by conventional spraying.

When the relationship between increasing concentrations of herbicides used in herbigation and $\mathrm{P}_{\mathrm{e}}$ was studied statistically, the data were best fitted to an exponential function showing that the superiority of sprinkler irrigation over drip irrigation is more noticeable in the higher concentrations of Metribuzin (Figure 3). With drip irrigation, herbicide molecules do not directly contact the weed leaf surface; they pass through the soil before being translocated upward in the xylem. This process is accompanied with detoxification processes.

Tomato yield (TY): With statistical adjustment of method of weed control effect, irrigation system had statistically significant effect $(p \leq 0.0001)$ on TY. Under sprinkler irrigation system, TY was significantly lower (4.5 ton/fed.) than that under drip irrigation system (4.97 ton/fed.). This could be due to the relatively high amount of water in the root zone, more water penetration, less evaporation losses, less salinity, better aeration and better fertilizers distribution, with drip irrigation as compared to sprinkler irrigation system.

With statistical adjustment of the irrigation system effect, the weed control method affected significantly $(\mathrm{p} \leq 0.0001)$ TY. The value resulted from hoe weeding was higher $(p \leq 0.05)$ than any value given by the other weed control methods studied. However, the conventional weeding method resulted in significantly similar ( $p \geq 0.05)$ TY values as hoe weeding method. Here again, herbigation with herbicide concentration of $0.150 \mathrm{~kg} / \mathrm{fed}$ showed significantly lower TY value $(\mathrm{p} \leq 0.05)$ than any other weeding method. Herbigation with $0.300 \mathrm{~kg}$ herbicide/fed. did not differ significantly ( $\mathrm{p} \geq 0.05)$ in TY from conventional spraying or herbigation with herbicide concentration of 0.225 $\mathrm{kg} / \mathrm{fed}$. The later showed slightly higher $(\mathrm{p} \geq 0.05)$ TY value than that with 0.150 $\mathrm{kg} / \mathrm{fed}$ concentration. It is noticeable that 
Table 2. Least squares means ( \pm standard error) of eradication percent, tomato yield and cost per tomato ton by irrigation system and weed control method.

\begin{tabular}{|c|c|c|c|}
\hline & $\begin{array}{l}\text { Eradication } \\
\text { percent, \% }\end{array}$ & $\begin{array}{l}\text { Tomato yield, } \\
\text { ton/fed }\end{array}$ & $\begin{array}{l}\text { Cost of weed control } \\
\text { per tomato, LE/ton }\end{array}$ \\
\hline \multicolumn{4}{|l|}{ Irrigation system (IS) } \\
\hline Drip & $48.83^{\mathrm{a}}$ & $4.97^{\mathrm{a}}$ & $13.18^{\mathrm{a}}$ \\
\hline Sprinkler & $51.02^{\mathrm{a}}$ & $4.15^{\mathrm{b}}$ & $16.35^{\mathrm{a}}$ \\
\hline S.E. & \pm 2.74 & \pm 0.25 & \pm 1.29 \\
\hline Level of significance & $\mathrm{p} \leq 0.581$ & $\mathrm{p} \leq 0.041$ & $\mathrm{p} \leq 0.110$ \\
\hline \multicolumn{4}{|c|}{ Weed control method (WCH) } \\
\hline No weeding & $0^{\mathrm{e}}$ & $0.34^{\mathrm{d}}$ & $0^{\mathrm{c}}$ \\
\hline Hoe weeding & $91.00^{\mathrm{a}}$ & $7.85^{\mathrm{a}}$ & $19.52^{\mathrm{a}}$ \\
\hline Conventional spraying & $76.15^{\mathrm{ab}}$ & $6.64^{\mathrm{a}}$ & $15.45^{\mathrm{a}}$ \\
\hline $\begin{array}{l}\text { Herbigation with } 0.150 \\
\text { herbicide } \mathrm{kg} / \mathrm{fed} .\end{array}$ & $23.80^{\mathrm{d}}$ & $2.29^{\mathrm{cd}}$ & $21.6^{\mathrm{a}}$ \\
\hline $\begin{array}{l}\text { Herbigation with } 0.225 \\
\text { herbicide } \mathrm{kg} / \mathrm{fed} .\end{array}$ & $49.27^{\mathrm{c}}$ & $4.33^{\mathrm{cb}}$ & $16.25^{\mathrm{a}}$ \\
\hline $\begin{array}{l}\text { Herbigation with } 0.300 \\
\text { herbicide } \mathrm{kg} / \mathrm{fed} \text {. }\end{array}$ & $59.35^{\mathrm{cb}}$ & $5.82^{\mathrm{ab}}$ & $15.76^{\mathrm{a}}$ \\
\hline S.E. & \pm 4.73 & \pm 0.44 & \pm 2.24 \\
\hline Level of significance & $\mathrm{p} \leq 0.0001$ & $\mathrm{p} \leq 0.0001$ & $\mathrm{p} \leq 0.0003$ \\
\hline$($ IS $) \times($ WCM $)$ interaction & $\mathrm{p} \geq 0.05$ & $\mathrm{p} \geq 0.05$ & $\mathrm{p} \geq 0.05$ \\
\hline
\end{tabular}

a; b; c; d: within each source of variation, means having different superscripts are significantly different at $\mathrm{p} \leq 0.05$. 
no weed control method gave comparable ( $p \geq 0.05)$ TY value relative to herbigation with $0.150 \mathrm{~kg} / \mathrm{fed}$. Decreased tomato yields at lower herbicide concentrations is due to weakening tomato crop stand, which resulted in the increased weeds competition for light, water and nutrients.

The quadratic equation fitting the data relating TY with herbicides concentrations used in herbigation, indicated that the superiority of drip system over sprinkler system increases with increasing herbicide concentration (Figure 4), as the competition between weeds and tomato plants decreases as herbicide concentration augments.

Weed control cost (WCC): At the same method of weed control, sprinkler irrigation did not differ significantly $(\mathrm{p} \geq 0.05)$ in WCC from drip system, (16.33 vs. 13.18 LE/ton, resp.). With statistical adjustment of irrigation system effect, methods of weed control did not differ from each other significantly $(\mathrm{p} \geq 0.05)$. However, it appears clearly that herbigation with herbicide concentration of 0.150 $\mathrm{kg} /$ fed would be carried at much lower cost (at least LE 4/ton) than any other weed control method studied. Similar trends are shown in the itemized costs given in Table (3).

Herbicide residues (HR): Table (4) gives results comparing herbigation (at different herbicide concentrations) with conventional spraying under the two irrigation systems applied. Under either sprinkler or drip irrigation systems, conventional spraying resulted in higher HR values than herbigation. Table (4) showed that HR values increased with the increase of herbicide concentration when herbigation was applied. HR values were greater with herbigation under sprinkler than under drip irrigation; the reverse being true with conventional spraying. It is noteworthy that at equal herbicide concentration of $0.300 \mathrm{~kg} / \mathrm{fed}$ conventional spraying resulted in much higher HR value than herbigation when comparison was made under drip irrigation. It should be emphasized that residues recorded in tomato fruits exceeded by far the international tolerance of Metribuzin. The only exception was the tomato fruits produced under drip irrigation using herbigation with herbicide concentrations of 0.15 and $0.225 \mathrm{~kg} / \mathrm{fed}$. which appeared free from herbicide residues.

The disappearance of Metribuzin residues at its lower concentrations under DI could be due to increase of herbicide degradation in the wet zone and its being readily leached in sandy soil. The increase in herbicide residues in fruits produced under sprinkler irrigation system was due to increase in the herbicide contaminated surfaces in both plant (leaves and stems) and soil. However, all the defected values of Metribuzin residues in tomato fruits that produced under sprinkler irrigation system exceeded overlooked the safety tolerance $(0.1 \mathrm{ppm}$ according to International Tolerances). Also, the decrease in herbicide residues in tomato fruits produced where weeds were controlled using conventional spraying under sprinkler irrigation system is attributed to increase in the herbicide molecules with frequent leaching of surfaces treated in plant and soil which resulted by through water droplets action of sprinkler system. 


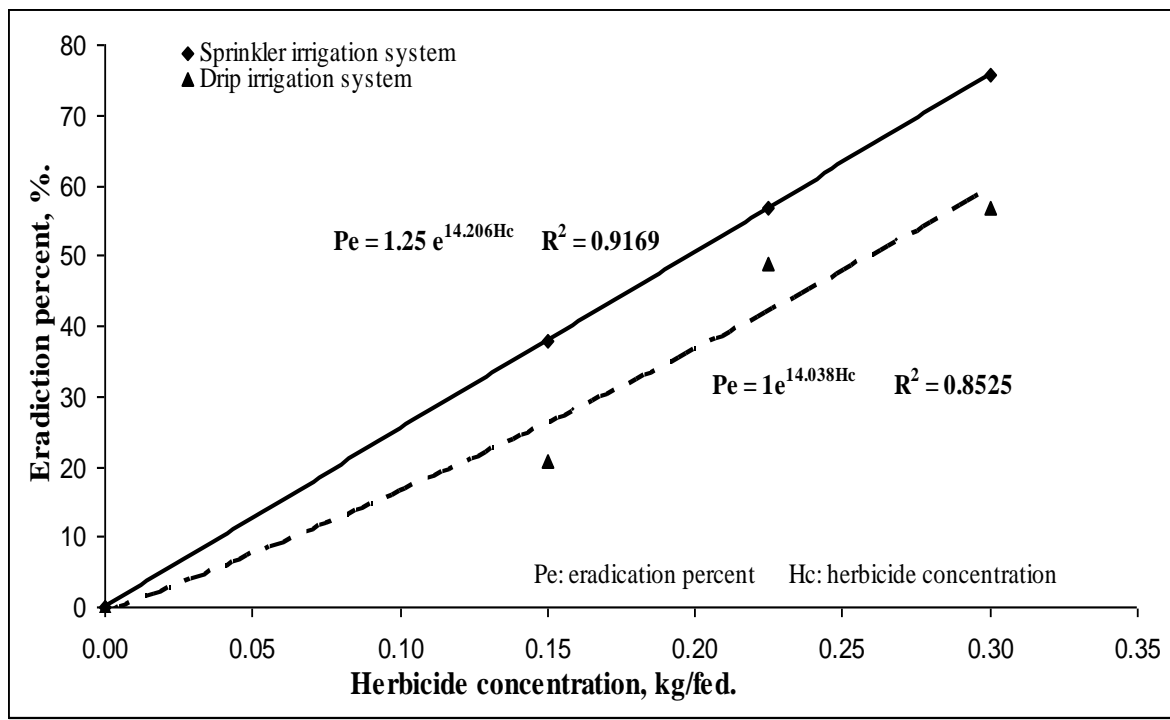

Fig. 3. Effect of the herbicide concentration on percentage of weed eradication under drip and sprinkler irrigation systems.

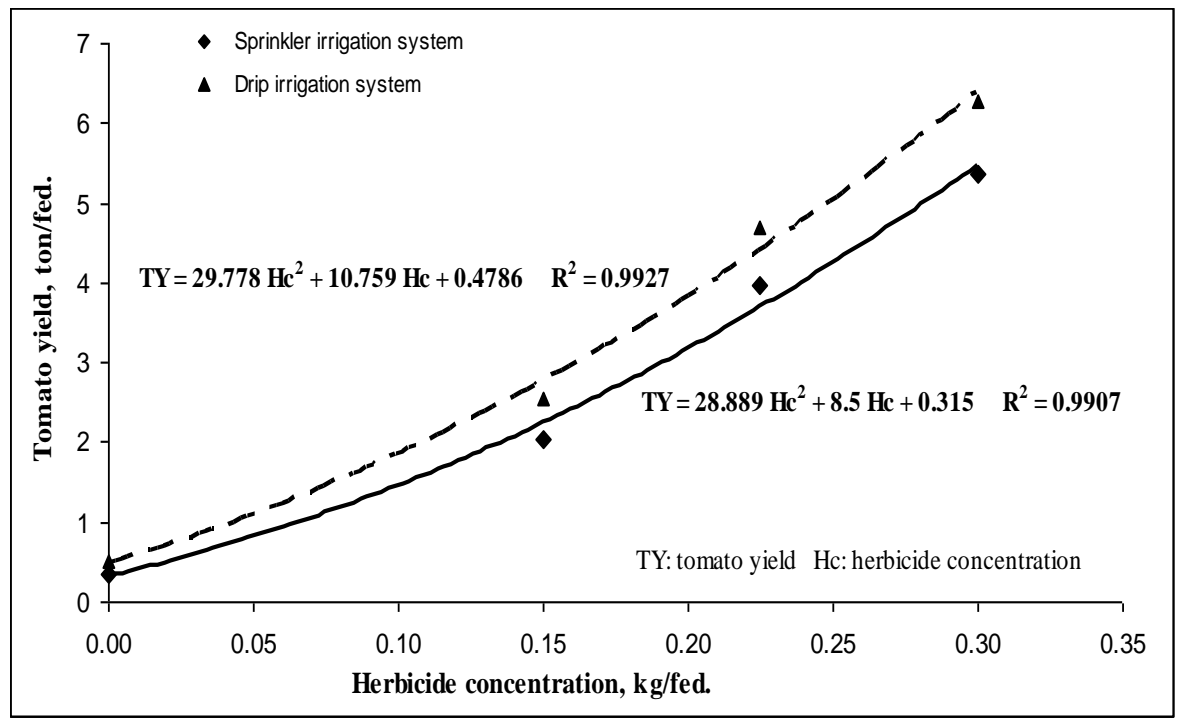

Fig. 4. Effect of the herbicide concentration on tomato yield under drip and sprinkler irrigation systems. 
Table 3. Cost elements of weeding operations per ton of tomato

\begin{tabular}{|c|c|c|c|c|c|c|c|c|c|c|}
\hline \multirow{5}{*}{ Item } & \multicolumn{10}{|c|}{ Cost, L.E. } \\
\hline & \multicolumn{5}{|c|}{ Drip irrigation system } & \multicolumn{5}{|c|}{ Sprinkler irrigation system } \\
\hline & \multirow{3}{*}{ H.W. } & \multirow{3}{*}{ C.S. } & \multicolumn{3}{|c|}{ Herbigation } & \multirow{3}{*}{ H.W. } & \multirow{3}{*}{ C.S. } & \multicolumn{3}{|c|}{ Herbigation } \\
\hline & & & \multicolumn{3}{|c|}{ Herbicide rate, $\mathrm{kg} / \mathrm{fed}$} & & & \multicolumn{3}{|c|}{ Herbicide rate, $\mathrm{kg} / \mathrm{fed}$} \\
\hline & & & 0.150 & 0.225 & 0.300 & & & 0.150 & 0.225 & 0.300 \\
\hline Depreciation & -- & 0.50 & 0.048 & 0.070 & 0.096 & -- & 0.50 & 0.026 & 0.037 & 0.053 \\
\hline Interest on investment & -- & 0.05 & 0.024 & 0.035 & 0.048 & -- & 0.05 & 0.013 & 0.018 & 0.029 \\
\hline Taxes & -- & 0.02 & 0.009 & 0.013 & 0.018 & -- & 0.02 & 0.005 & 0.007 & 0.010 \\
\hline Repairs and maintenance & -- & 0.60 & -- & -- & -- & -- & 0.60 & -- & -- & -- \\
\hline Operator salary & $150^{*}$ & $10.0^{* * *}$ & -- & -- & -- & $150^{*}$ & $10.0^{* * *}$ & -- & -- & -- \\
\hline Herbicide cost & -- & 90.0 & 45.0 & 67.5 & 90.0 & -- & 90.0 & 45.0 & 67.5 & 90.0 \\
\hline Total costs per fed. & 150 & 101.17 & 45.081 & 67.618 & 90.162 & 150 & 101.17 & 45.044 & $67.062 \mathrm{~s}$ & 90.092 \\
\hline Costs per ton tomatoes & 17.42 & 14.05 & 17.68 & 14.42 & 14.36 & 21.12 & 216.64 & 22.19 & 16.89 & 16.80 \\
\hline
\end{tabular}

H.W $=$ Hoe weeding $\quad$ C.S. $=$ Conventional spraying

* Hoe weeding one feddan needs about 15 operators (assuming 10 L.E. operator wage per day).

** Conventional spraying one feddan needs about one operator per day.

Table 4. Residues of Metribuzin herbicide in tomato fruits as affected by the weed control methods

\begin{tabular}{|c|c|c|c|c|}
\hline \multirow{3}{*}{ Irrigation system } & \multicolumn{4}{|c|}{ Residues in tomato fruits, ppm. } \\
\hline & \multicolumn{3}{|c|}{ Herbicide concentration, $\mathrm{kg} / \mathrm{fed}$. } & \multirow{2}{*}{$\frac{\text { Conventional spraying }}{0.300 \mathrm{~kg} / \mathrm{fed} .}$} \\
\hline & 0.150 & 0.225 & 0.300 & \\
\hline Drip & free & free & $15.70^{*}$ & $40.51^{*}$ \\
\hline Sprinkler & $2.48^{*}$ & $15.76^{*}$ & $20.24^{*}$ & $20.85^{*}$ \\
\hline
\end{tabular}

* International tolerance of metribuzin residues in tomato fruits of $0.1 \mathrm{ppm}$ 


\section{REFRENCES}

A.O.A.C. (1990). Multi-residues Methods: Federal Methods for Organochorine and Organophosphorous Pesticides. Assoc. Official. Anal. Chem. 13: 466472.

Alabi, B.S.; A.A. Osobu; J.O. Makinde; O.F. Owolade; E.A. Makinde and A.O. Ayeni (2004). Tillage and Herbicide Application Affect Weed Control and Performance of Tomato. New directions for a diverse plant. Proceedings of the $4^{\text {th }}$ International Crop Science Congress, Brisbane, Australia, ISBN 1 9208420 20 9: 320-327.

Awady, M.N.; M.J. El-Nono; E.A. ElSahhar and A.J. Aboud (2003). Application of Solar Energy for Drying Animal Wastes. Proc. $11^{\text {th }}$ Annual Conference of Misr Soc. of Ag. Eng.,: 347-361. Kafr El-Sheikh, Egypt.

Duncan, D.S. (1955). Multiple Range and Multiple Tests. Biometrics, 11: 142.
Eberlein, C.V.; B.A. King and M.J. Guttieri (2000). Evaluating an Automated Irrigation Control System for SiteSpecific Herbigation. Weed Technology, I: 0890-037X, 14(1): 182-187.

Frost, P.; G. Barnes; B. Bieche and X. Branthome (2003). Evaluation of New Herbicides for Management of Black Nightshade (Solanum nigrum) in Processing Tomatoes. Proc. of the $8^{\text {th }}$ International, pp. 201-203. Istanbul, Turkey.

Liaqat, W. and A. Nawab (2002). Effect of Different Weeding Strategies and Their Intensity on Tomato Crop. Sarhad. J. of Ag. Pakistan, 18(4): 367-369.

SAS (1988). SAS Procedures Guide, Release 6.03 Edition, SAS Institute INC., Carry, NC.

Sujith, G.M.; S.S. Chandrakumar and S. Seshadri (2003). Herbigation: a New Vision for Weed Management-A Review. Crop Res. 26(2): 189-197.

Ward, M.I.H. (2001). Effect of Different Weeding Control Methods for Faba Bean on Pollution of Soil-Plant Ecosystem. Misr J. Ag. Eng., 18(2): 309-323. 
بحلة اتحاد الجامعات العربية للدراسات والبحوث الزراعية ، جامعة عين شمس ، القاهرة ،14(2) ، 2006 (589 ، 2006 ،

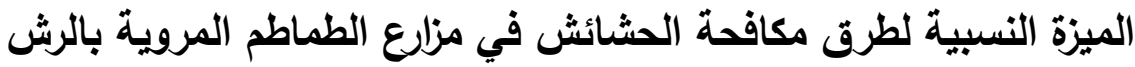
وإلتقيط في الأراضي المصرية حديثة الاستصلاح

[37]

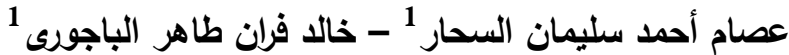

1- قسم الهنسة الزراعية- كلية الزراعة- جامعة عين شمس - شبرا الخيمة- القاهرة- مصر

الطماطم. ودرس كذللك متبقيات المبيد في

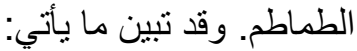

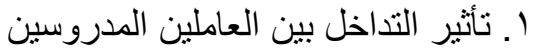

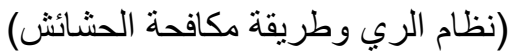

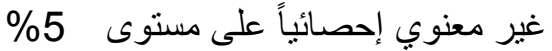
بالنسبة لتأثير ها على صفات اليات على الإبادة و المحصول و التكلفة.

r. بالتصحيح الإحصائي لأثر طريقة مكافحة

الحشائش فإن طريقة الري لم تكن ذات لاتئرة

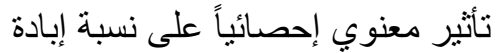

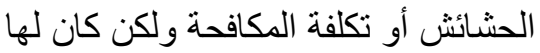

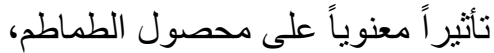

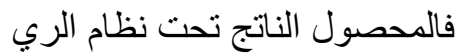
بالتنقيط كان أعلى من ذللك الناتج تحت

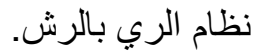
r. بالتصحيح الإحصائي لتأثير نظام الري لنالثي

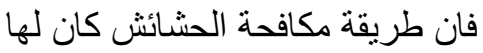

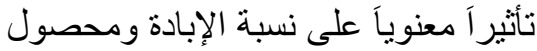

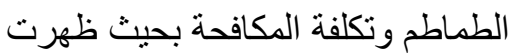

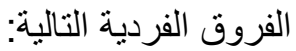
أ ـ العزيق اليدوي أعطى أعلى نسبة إبادة

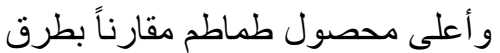

أجريت هذه الدر اسة المبنية على مشروع تعاون مع المجالس الإقليمية للبحوث الإند

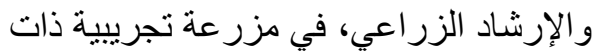

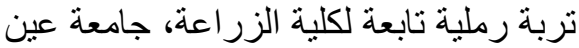

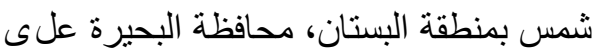
موسمين ( 2004، ان 2005) في مساحة

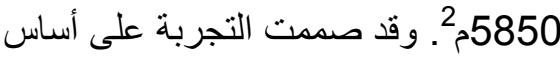
القطع المنشقة الكاملة مرتبة في قطع عشو ائية كاملة حيث طبق نظامين للري

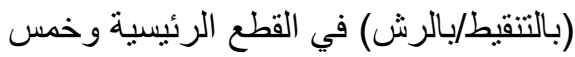
طرق لمكافحة الحشائش (بالعزيق اليدوي)

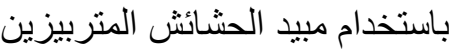

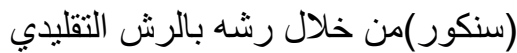

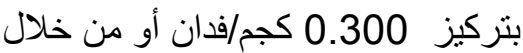
إضافته في مياه الري بثلاثة تركيز

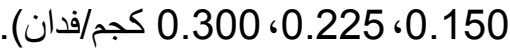
وقد أجرى التحليل الاحصائى للنتائج بطريقة المربعات الدنيا بنموذج ينضمن الاحتي العاملين: نظام الري وطريقة مكافحة الحشائش و التداخل بينهما فيما بتعلق بتأثنير ها على نسبة الإبادة ومحصول الطماطم/ فدان ونصيب مكافحة الحشائش من تكلفة إنتاج 
نظام الري بالتنقيط على نظام الري

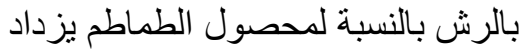

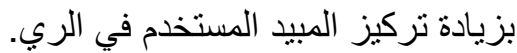
ع. تحت أي من نظامي الري فإن المكافحة

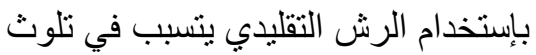

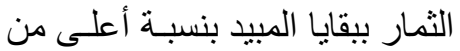

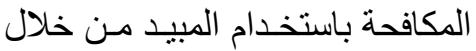

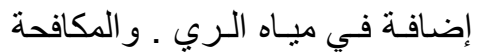

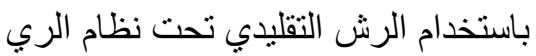

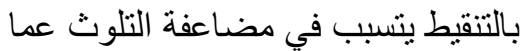
لو استخدم الرش التقليدي تحت نظام

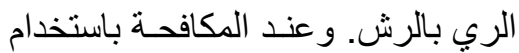

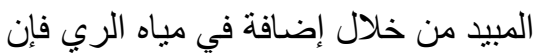

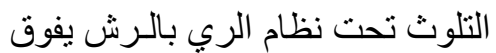
التلوث تحت نظام الري بالتنقيط.

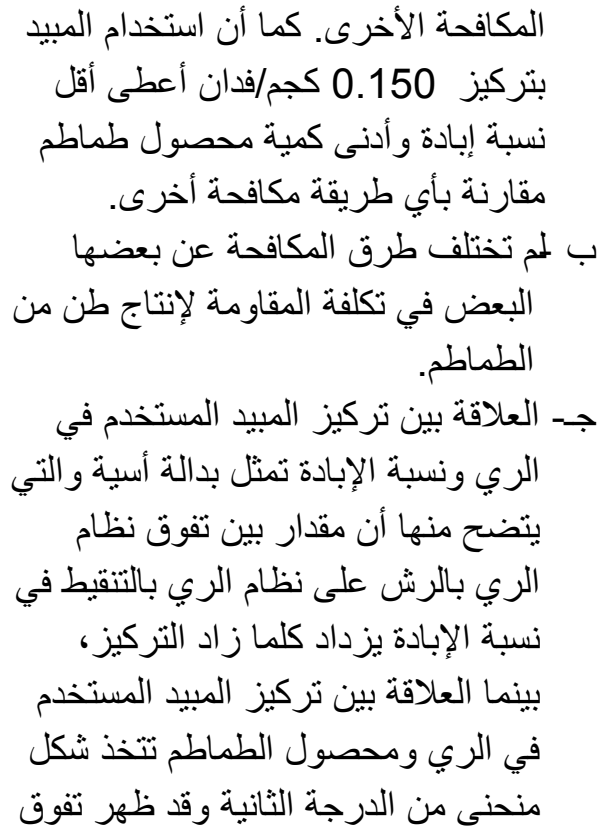

تحكيم: أ.د عبد الغنى محمد الجندى إمام سليمان أ.د أحمد الر اعى إمام سليمان 